\title{
Age structure of coniferous saplings in mountain old-growth forests of the Middle Urals
}

\author{
Natalya Ivanova ${ }^{1, *}$ and Irina Petrova ${ }^{1}$ \\ ${ }^{1}$ Botanical Garden of the Ural Branch of the Russian Academy of Sciences, 620144, Yekaterinburg, \\ Russian Federation
}

\begin{abstract}
The processes of natural reforestation play a crucial role for the preservation of primary coniferous forests and the success of their restoration after catastrophic impacts. The objective of our research was to identify the features of the natural renewal of the main coniferous forestforming plants under the canopy of stands in the mountains of the Middle Urals, to establish dependencies on the forest type not only the total number of tree saplings, but also its age structure. The research was carried out in the mountainous part of the Sverdlovsk region (Russia) on the eastern macroslope of the Ural Mountains. We studied old-age pine forests, which belong to the 4 most common forest types. The tree saplings were counted into account on 2-4 subplots with a length of 20 meters and a width of 2 meters. It is established that under the canopy of all types of forest there is a different age coniferous saplings, despite significant differences in habitats. The most abundant pine saplings are found in pine forests with Vaccinium vitis-idaea, and the most abundant spruce saplings is found in pine forest with spruce and moss cover.
\end{abstract}

\section{Introduction}

The progressive human impact on natural ecosystems on all continents and undesirable climate changes reduce the stability of the biosphere and lead to threats of local and global environmental crises [1]. At the same time, forest ecosystems are recognized as one of the main factors that can reduce the undesirable consequences of these impacts and maintain the biosphere in a stable state [2, 3]. Moreover, primary forests perform much better ecosystem functions than secondary plant communities [4]. Therefore, the problem of primary forest conservation is recognized as extremely urgent. S.A. Dyrenkov [5] was the first to point out the need to solve this problem in Russia. However, despite the recognition of the importance of preserving primary forests, their areas continue to decline [6]. The processes of natural reforestation play a crucial role for the preservation of primary coniferous forests and the success of their restoration after catastrophic impacts [1]. The presence or absence of coniferous saplings under the forest canopy is a "trigger" of recovery-age shifts after logging, and the ability to appear and survive seedlings of woody plants in open habitats determines the success of natural reforestation after

\footnotetext{
*Corresponding author: i.n.s@bk.ru
} 
deforestation [7]. However, the processes of natural regeneration, which have their own characteristics in different regions and types of forest, are not fully understood.

The objective of our research was to identify the features of the natural renewal of the main coniferous forest-forming plants under the canopy of stands in the mountains of the Middle Urals, to establish dependencies on the forest type not only the total number of tree saplings, but also its age structure.

\section{Materials and Methods}

\subsection{Study area}

The research was carried out in the mountainous part of the Sverdlovsk region (Russia) on the eastern macroslope of the Ural Mountains. The mountains studied did not exceed an altitude of 500 meters above sea level. Annual rainfall in the study area varies between 400 and $500 \mathrm{~mm}$ per year. Southern taiga pine forests grow here. Birch (Betula pubescens Ehrh., B. pendula Roth), larch (Larix sibirica Ledeb.), and linden (Tilia cordata Mill.) are found everywhere in primary pine forests. This region is characterized by a variety of forest types, each of which has its own characteristics of structure and recovery dynamics after disturbances. The classification of the studied forests is based on the genetic forest typology, which is widely used in Russia both in scientific research and in forest management $[8,9]$. B. Kolesnikov and his colleagues, after extensive long-term research, compiled a brief but succinct description of all forest types in the Middle Urals [10].

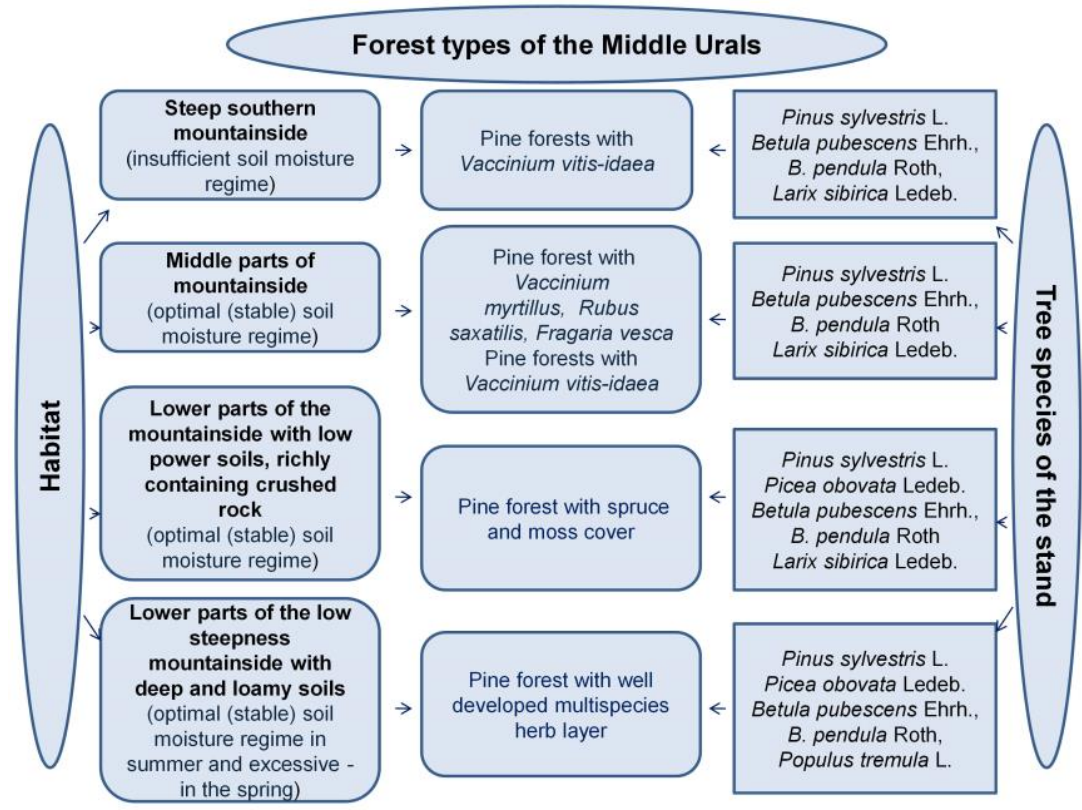

Fig. 1. Studied pine forest types in the mountains of the Middle Urals

\subsection{Sampling and measurements}

The sample plots are laid out in different pine forest types, which occupy different positions in the terrain (Fig. 1). The size of the sample plots was 0.25 hectares. The overstorey and 
understorey layers were studied according to the methods generally accepted in forest science [11]. The tree saplings were counted into account on 2-4 subplots with a length of 20 meters and a width of 2 meters. The species composition, height, diameter, basal area, and age are defined for the stand and tree saplings. The species composition, height, coverage, and biomass are determined for the understorey layer. A description of the structure of the studied forest types and their comparison with the mountain forests of the Southern Urals was presented earlier [6, 12].

\section{Results and Discussion}

We continued the work of Boris Kolesnikov [10] on the study of forest types in the Ural Mountains in our research. This report is devoted to the forest typological features of renewal under the canopy of primary forests. As shown by the results of research, old-age (more than 160 years) - pine forests with Vaccinium vitis-idaea are characterized by abundant pine young growth of different ages (Fig. 2a). At the same time, small tree saplings under the age of 10 years are predominant. The stand of these forests is pine, monodominant with a single admixture of birch and larch (Fig. 1). The height of the stand reaches 24 meters, the pine basal area is $44 \mathrm{~m}^{2} /$ ha. Abundant renewal of pine trees of different ages is also noted in berry pine forests. The predominant generation is under 20 years of age (Fig. 2b). Nevertheless, individual specimens of severely depressed 30-45year-old tree saplings can be observed everywhere in this forest type. The stand also has a similar structure to the cowberry pine forests.
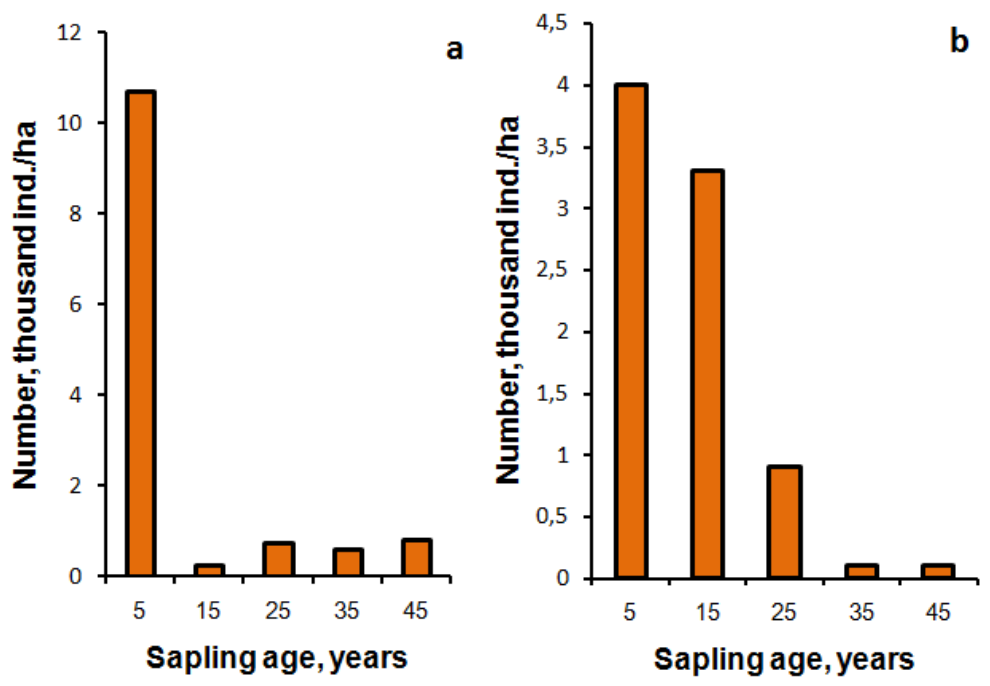

Fig. 2. Age structure of saplings of Pinus sylvestris L. in mountain old-growth pine forest: a - Pine forests with Vaccinium vitis-idaea, b - Pine forest with Vaccinium myrtillus, Rubus saxatilis, Fragaria vesca

Pine forest with spruce and moss cover are one of the most interesting forest types. In this forest type, abundant spruce and fir renewal is observed under the canopy of the pine stand (Fig. 3). Spruce and fir form a closed layer in this forest type. The distribution of tree saplings by age is fairly uniform. The height of the investigated stand reaches 25 meters, the pine basal area is $29 \mathrm{~m}^{2} /$ ha, the spruce basal area is $2 \mathrm{~m}^{2} /$ ha, the larch basal area can reach $4 \mathrm{~m}^{2} / \mathrm{ha}$. Besides that, the presence of spruce saplings under the pine canopy is noted in multi-herb pine forests (Fig. 4). However, a pine sapling prevails in this forest type. The pine and spruce sapling do not form a closed layer in this forest type, although its diversity of ages persists. The age of the studied stand was 150 years, the height of the stand reaches 
28.9 meters, the pine basal area is $35.5 \mathrm{~m}^{2} / \mathrm{ha}$, and birch basal area is $6.5 \mathrm{~m}^{2} / \mathrm{ha}$. The results obtained are in good agreement with the studies of other authors [13, 14].
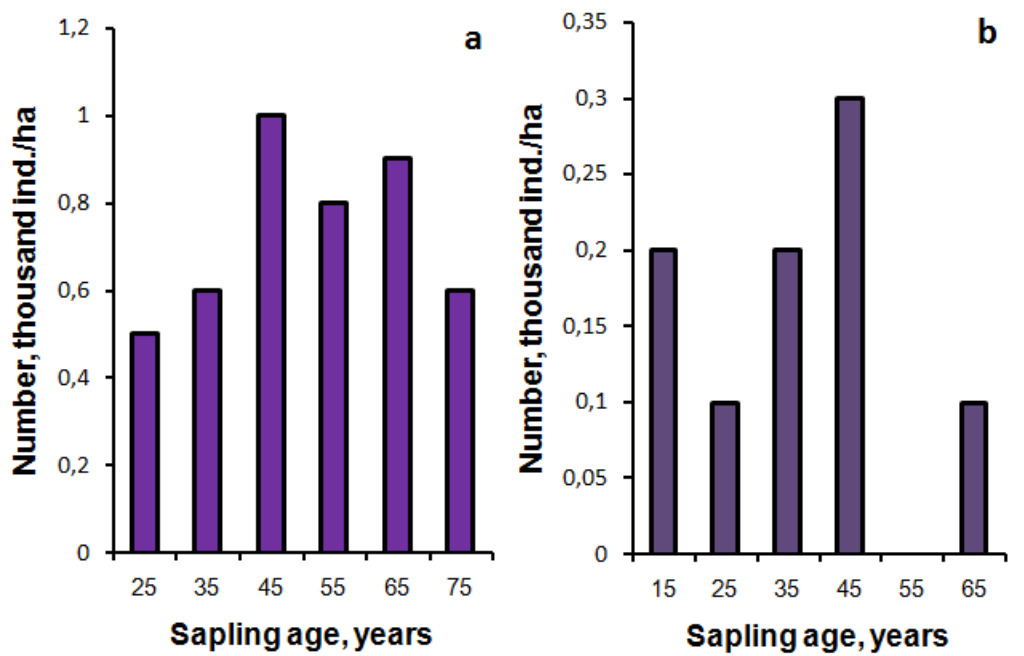

Fig. 3. Age structure of coniferous saplings in mountain old-growth Pine forest with spruce and moss cover: a - saplings of Picea obovata Ledeb., b - saplings of Abies sibirica Ledeb.
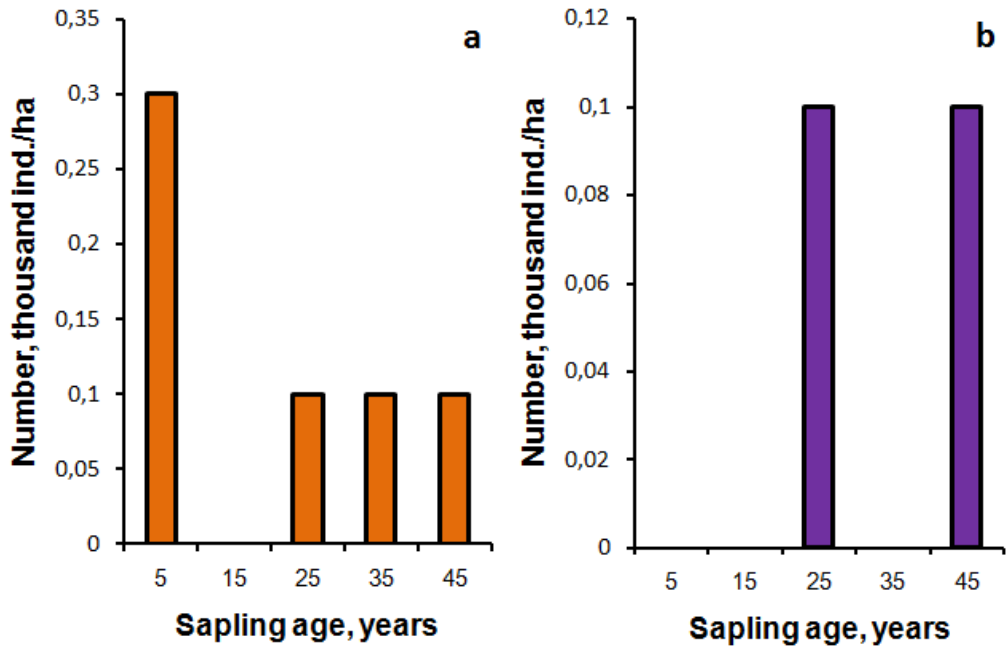

Fig. 4. Age structure of coniferous saplings in mountain old-growth Pine forest with well-developed multispecies herb layer: a - saplings of Pinus sylvestris L., b - saplings of Picea obovata Ledeb.

\section{Conclusions}

We studied old-age pine forests, which belong to the 4 most common forest types in the mountains of the Middle Urals, and established that under the canopy of all forests there is a different age coniferous saplings, despite significant differences in habitats. The most abundant pine saplings are found in the pine forests with Vaccinium vitis-idaea, and the most abundant spruce saplings is found in pine forest with spruce and moss cover. The results obtained are important for the preservation of primary forests and their restoration after destructive natural and human impacts in the Ural Mountains. 
The work was carried out within the framework of the state task of the Botanical Garden of the Ural branch of RAS

\section{References}

1. R. Maiti, H.G. Rodriguez, N.S. Ivanova, Autoecology and Ecophysiology of Woody Shrubs and Trees: Concepts and Applications (John Wiley \& Sons, Ltd, New York, 2016)

2. A. Sidder, Eos, 101, 142166 (2020)

3. K.M.S. Kemppinen, P.M. Collins, D.G. Hole, Ch. Wolf, W.J. Ripple, L.R. Gerber, Conservation Biology 34 (5), 1221-1228 (2020)

4. N.S. Ivanova, E.S. Zolotova, G. Li, Ecological Questions 32(2), 1-18 (2021)

5. S.A. Dyrenkov, Structure and dynamics of taiga spruce forests (Nauka, Leningrad, 1984)

6. N.S. Ivanova, Sustainable Bioresource Management, 29-52 (Apple Academic Press, New York, 2020)

7. S.N. Sannikov, I.V. Petrova, N.S. Sannikova, A.A. Kochybei, D.S. Sannikov, Rus. J. of Ecol. 48(4), 340-349 (2017)

8. V. Fomin, N. Ivanova, A. Mikhailovich, IOP Conference Series: Earth and Environmental Science, 609(1), 012044 (2020)

9. V. Fomin, A. Mikhailovich, S. Zalesov, A. Popov, G. Terekhov, Baltic Forestry, 27(1), $466(2021)$

10. B.P. Kolesnikov, R.S. Zubareva, E.P. Smolonogov, Forest vegetation conditions and forest types of Sverdlovsk oblast. Field guidance (Scientific Training Center the USSR Academy of Sciences, Sverdlovsk, 1973)

11. N. Ivanova, Biology, Productivity and Bioenergy of Timber-Yielding Plants: An Experimental Technology, 121-137 (SpringerBriefs in Plant Science. Springer, Cham, 2017)

12. N.S. Ivanova, Int. J. of Bio-resource and Stress Management, 10, 251-256 (2019)

13. E.S. Zalesova, S.V. Zalesov, G.G. Terekhov, O.V. Tolkach, N.A. Luganskiy, D.A. Shubin, Advances in current natural sciences (Uspekhi sovremennogo estestvoznaniya) 1, 39-44 (2019) (In Russian)

14. N.N. Terinov, E.M. Andreeva, S.V. Zalesov, N.A. Lyganskiy, A.G. Magasumova, Lesnoy Zhurnal (Russian Forestry Journal), 3, 9-23 (2020) (In Russian) 